\title{
Recognize the Characteristic and Make Innovations in the Running of Part-time Master of Engineering
}

\author{
Changbin Zhang* \\ Dalian Jiaotong University, Bidding and purchasing center, 116028, Dalian, China \\ *Corresponding author. Email: zcb@djtu.edu.cn
}

\begin{abstract}
In view of the present situation of part-time master of engineering training in our country, from the height of the school-running idea, the characteristics of innovation, the article explains how to from the training scheme, course construction, teaching courseware, paper work, and teaching management work at the characteristic of part-time master of engineering education innovation.It correctly handles the relationship between the above several aspects and promotes engineering master major degree education fully adapt to the need of social and economic development in our country, makes a part-time master of engineering education for the purpose of social services for the enterprise.
\end{abstract}

Keywords: Part-time master of Engineering, School philosophy, Characteristic innovation.

\section{INTRODUCTION}

Ten years after China's entry into the WTO, the market economy system constantly improve, and enter the new period our country comprehensive construction affluent society's goal of implementation. The part-time postgraduate education is an important form in the development of graduate education. The part-time professional master degree of engineering education in the new development opportunities, it also shoulder the important mission and responsibility. At present, China's economic and social development has entered a new normal, with the acceleration of economic restructuring, transformation and upgrading. The concept of "mass entrepreneurship and innovation" is gaining popularity. The construction of "lifelong education" and "learning society" is in full force. Only with a clear understanding of the education philosophy of master of Engineering and a correct handling of the relationship between training programs, curriculum construction, courseware, thesis work, teaching management and other aspects, we can innovative part-time master of Engineering degree education and keep pace with The Times, and fully meet the needs of China's social and economic development.

\section{THE FORMULATION OF THE TRAINING SCHEME FOR PART-TIME MASTER OF ENGINEERING SHOULD BE COMBINED WITH THE ACTUAL NEEDS OF ENGINEERING}

Training plan is the standardization of the high-level talent training files. About the degree authorization is one of the concrete embodiment of training objectives and master's degree required. It is to organize teaching and guidance of dissertation research platform and the important basis of education administration of quality supervision, inspection and evaluation. The master is to train and develop the core of the work of conferring academic degrees and quality guarantee system. Our school fully considers the needs of part-time master of Engineering, carefully formulated 11 training programs in the authorized fields of master of Engineering degree, and supplemented and revised the training programs for master of Engineering students many times according to the actual engineering needs of the training base for master of Engineering students.

\subsection{Distinct Practicality}

In accordance with the national purpose of establishing part-time master of Engineering, our school always emphasizes that the training program of master of Engineering can reflect the training ability of solving practical engineering problems and engineering 
innovation ability. According to the actual needs of related engineering fields and the research direction of the tutor team. The research direction of part-time master of Engineering students is established and the research scope is generally broadened. When it is determined the research direction of each engineering field in our school, we have organized relevant experts in the school and experts and technicians from corresponding enterprises to jointly demonstrate. Such as locomotive vehicle engineering institute according to the engineering master in part-time work in the rolling stock, the condition of the related disciplines within the organization related institute and technical personnel of locomotive vehicle co., LTD., demonstrate the important research direction in the field of vehicle engineering, and eventually determine several important research direction in the field of vehicle engineering, choose for part-time engineering master. There are several points reflected in the training scheme. Firstly, the practice link is enhanced in the training process; The second is the course teaching. The theoretical study is set closely around the practical needs to reflect the purpose of learning for practical use. Thirdly, the thesis plan encourages engineering masters to take project development, project design and other engineering innovations and scientific research summaries as their dissertations, so as to train their ability in engineering from practice to theory, and then from theory to practice.

\subsection{The Course System of Part-time Master of Engineering is Set up According to the Principle of Practicality}

The course learning of part-time master of Engineering students should be broad, comprehensive, advanced and practical. According to the training objectives in the engineering field and the actual needs of the unit where the master of Engineering is located. Degree courses and compulsory courses are determined according to the engineering field. Students may choose some non-degree courses according to their own work situation and interests, or take elective courses in the interdisciplinary field. According to the characteristics of master of Engineering, flexible and diverse teaching methods are adopted according to the course content, such as giving priority to the key and difficult points in classroom teaching, self-study, course discussion and special lectures, etc., and multimedia teaching is actively adopted in many courses. On the basis of the principle of diversity and flexibility in the setting of basic professional courses and professional courses, and fully considering the ability, quality, foundation and interest of graduate students as well as the objective needs of engineering, as many courses are set up as possible, and more elective courses are set up, so as to facilitate the selection of students engaged in different engineering research directions.

\section{TO SET UP COURSES THAT REFLECT THE CHARACTERISTICS OF PART-TIME MASTER OF ENGINEERING DEGREE EDUCATION}

Course learning is an important and critical part of the training of part-time master of Engineering. The education of engineering master degree should be reformed and developed to cultivate high-level applied talents for social development and economic construction. The core of the education is curriculum construction, because curriculum is the blueprint of talent planning. The key to realize the educational purpose lies in curriculum.

The curriculum setting of part-time engineering master's degree education should not only ensure the basic quality of graduate education, but also fully reflect the characteristics of professional degree education. However, looking at the current situation of the curriculum construction of part-time master's degree in Engineering in China, we can find the following problems. The failing to fully reflect the characteristics of professional degree education. The course structure is not reasonable. The lag of curriculum and curriculum setting concept. In view of the above problems and in combination with the development trend of the professional degree education of part-time master of Engineering in China, our school believes that the current curriculum setting mode must be reformed in order to cultivate talents with comprehensive development and adapt to the needs of social and economic development. Our school believes that in the process of reform, we must follow the following principles: the principle of unity of universality and particularity, the principle of attaching equal importance to professionalism and theory, the principle of unity and diversity combined, the principle of combining science education with humanities education.

Our school's part-time master of Engineering program emphasizes the close combination with practice. The curriculum is set in accordance with the principle of "combining learning with application and supporting research", so as to guide the practice theoretically. From the teaching plan, teaching outline, teaching task, curriculum setting and teaching assessment system of part-time master of Engineering, practical teaching has obvious separation, which is mainly reflected in the course experiment, course design, engineering practice and degree thesis and other practical links. To strengthen the cultivation of the practical ability of engineering master students, it is necessary to gradually put the practical teaching course through the course teaching and at the same time put the course teaching through the practical teaching. In terms of practical teaching, our school has strengthened the cooperation between production, education and 
research, and established a number of stable practice bases outside the school.

\section{SELECT SPECIAL TEACHING MATERIALS SUITABLE FOR PART-TIME MASTER OF ENGINEERING}

The construction of teaching materials and courseware is an important link in postgraduate education. It is no longer suitable to replace the teaching material of master of Engineering with the original teaching material of master of engineering. Engineering master students are from industrial and mining enterprises with rich practical experience, strong practical ability and clear learning purpose. In particular, they need to learn the knowledge to solve practical problems in production, scientific research and technological transformation of enterprises. Non-full-time engineering master candidates are generally the backbone of the enterprise, graduation years are longer, some theoretical knowledge has mostly forgotten, and the relative aging of knowledge, English and computer skills are generally weak, the same engineering master level is uneven, lack of modern science and technology and management knowledge. Because be on-the-job study again, the job is busy, study time cannot get safeguard. Whether it is their own characteristics or the practical problems faced by graduates, part-time master of Engineering students and master of Engineering students are very different. It is necessary to choose courseware that adapts to the characteristics of part-time master of Engineering and meets the training requirements in the field of engineering to meet the needs of the development of master of Engineering education. The formulas, charts and related knowledge frequently used in the work of part-time master of engineering are used as appendices for checking. Some important but theoretical contents are compiled into courseware for students to learn by themselves.

The public basic teaching materials for part-time master of Engineering students are related to the study of subsequent courses and the requirements of the dissertation. So the selection of materials is very important. Through the joint efforts of our graduate school and teachers, we have carefully selected practical teaching materials suitable for the characteristics of part-time master of engineering students. This marks that the training of part-time engineering masters in our school has stepped out of a solid step towards standardization. After completing this course, part-time master of Engineering students should have a leap in knowledge structure.

\section{ENSURE THE QUALITY OF DISSERTATION, REFLECT THE CHARACTERISTICS OF INNOVATION}

Since the enrollment of part-time master of Engineering in 1997, strict examination and supervision have been carried out on the dissertations of part-time master of engineering, which has greatly guaranteed the quality and level of the dissertations of master of engineering. At present, the thesis of part-time master of Engineering mainly highlights two characteristics. One is that the thesis topic is closely related to the engineering practice. Second, in the process of doing the thesis, the project results have produced better economic and social benefits. But at the same time, there are still some problems. First of all, students study style is blundering, no attention to the cultivation of writing ability, students muddle along, the dissertation work enough emphasis, demand is not high, only to graduate, get a degree, lead to in the dissertation as page upside down, important data, graph and image content disconnect, wrong characters and paper logic is not strong. Secondly, the basic theory and professional knowledge are not solid enough. Finally, the enterprise innovation investment is limited, leading to the part-time engineering master's degree thesis innovation point is not much. Only by strengthening the quality control of master of Engineering dissertations and solving the above problems, we can truly achieve dissertation innovation.

Innovation is the key to master's degree thesis, and the same is true for part-time master's thesis of engineering. Without innovation, an engineering master's thesis is hardly a complete master's thesis. Master of Engineering students are mostly on-the-job and have limited access to information. Therefore, our school tries its best to build the way and platform for them to obtain the latest and most complete information, and encourages the engineering master students to make bold innovation and actively apply the results into practice. In addition, the tutor gives timely guidance to the master of engineering students, urges them to carefully consult literature and guides their thinking innovation, and inspires the master of engineering students from two aspects: strengthening the cultivation of innovation ability and solving practical problems.

\section{STANDARDIZE THE MANAGEMENT SYSTEM ACCORDING TO THE CHARACTERISTICS OF PART-TIME MASTER OF ENGINEERING}

According to the characteristics of part-time master of Engineering in our school, we have realized that only by standardizing the training process and management system we can ensure the quality of master of Engineering. Only by working hard on management we 
can achieve good results. The origin and characteristics of master of Engineering students determine that their management methods should also be different.

\subsection{Implement the Management Mode with Target Management as the Main and Process Management as the Auxiliary}

Part-time engineering masters adopt the training mode of "entering the school and not leaving the post", and most of the learning and subject research are carried out in the unit. It is not easy to realize the process management of their learning and subject research. So the method should be given priority to by target management and supplemented by process management. For some of the daily management and part of the process management can be entrusted to the organization.

\subsection{Both Service and Management are Important}

Part-time master of engineering students not only to work, but also to complete the course learning and research task, it is a lot of difficulties. They study in school for a shorter time, to the school, the details of training do not know much. Therefore, colleges and graduate education management departments that cultivate engineering masters should provide comprehensive consulting services in teaching, scientific research and dissertations. All contents listed in target management must be subject to high standards, strict requirements and strict management. Pay equal attention to service and management, we must improve the training quality of part-time engineering masters.

\subsection{Implement the School-enterprise Joint Management System}

One of the characteristics of the training of part-time engineering masters is the joint training and management of schools and enterprises. The school focuses on the management of cultivation, while the unit focuses on the management of political thought, daily management and part of cultivation. Therefore, the close cooperation and joint management between school and enterprise is the necessary link to do well the training work of engineering master students and improve the training quality.

Our school cultivates talents for enterprises, especially for large and medium-sized enterprises, promotes production for enterprises to tackle technical problems, and promotes the development of teaching, scientific research and teachers in our school. We deeply feel that the training and management of part-time master of Engineering is not only an arduous work, but also a lofty and glorious educational undertaking. We must not only manage well, but also serve well. It is not only necessary to complete the task of management, but also from the characteristics of part-time master of engineering students, pay attention to management innovation, constantly explore, and strive to improve the quality of training, in order to do a good job of part-time master of engineering school innovation.

\section{CONCLUSION}

The cultivation of part-time engineering master's students is related to the reputation of the university. The most important thing is to do a good job in training students so that what they have learned can be used for their work.

\section{REFERENCES}

[1] Liu Huiqin, Shen Yan, Yong Cuiju. Practice and Innovation of engineering Postgraduate education.Tsinghua University Press, 2003.9

[2] Xia Fengyun, Song Xieqing. Some understandings on strengthening the quality management of engineering master degree thesis [A].Zhang jh. The theory of Degree and Postgraduate Education [C].Liaoning University Press, 2005, pp.448-453.

[3] Tong Yuanwei. Practice and Reflection on graduate Education of Engineering [J].Higher Education research in the Machinery Industry, 2002, (3), pp. 82-84.

[4] Liu Xianjun, Jiao Xiaomin, Wang Jianping. Practice and Exploration of Master of Engineering Education [J].Transportation Higher Education Research, 2002, (1), pp. 52-53.

[5] Su Na, Luan Weiling, Huang Sheng. Research on the Current Situation, Problems and Countermeasures of school-enterprise Collaborative Practice Education Mechanism Construction -- Taking the practice Teaching of Full-time Engineering Degree as an example [J].Chemical Higher Education, 2017, (5) ,pp. 14-20.

[6] Liu Jing. Mechanism Research on the Practice of full-time Master of Engineering Under the mode of industry-education integration [J].Industry and Information Technology education, 2019, (7), pp.30-34. 